Parallax

\title{
Noise on Noise
}

\section{Zafer Aracagök}

To cite this article: Zafer Aracagök (2006) Noise on Noise, Parallax, 12:4, 99-112, DOI: 10.1080/13534640600956040

To link to this article: https://doi.org/10.1080/13534640600956040

Published online: 24 Nov 2006.

Submit your article to this journal

Џ Article views: 46 


\title{
Noise on Noise
}

\author{
Zafer Aracagök
}

\begin{abstract}
Passing now from the genus to the species, I have to denounce as the most inexcusable and scandalous noise the truly infernal cracking of whips in the narrow resounding streets of towns; for it robs life of all peace and pensiveness. Arthur Schopenhauer ${ }^{1}$
\end{abstract}

0.

Or rather, what did Schopenhauer hear when he was disturbed by the cracking of whips and decided to write about noise? What was it so disturbing in the cracking of a whip? A philosopher from whom Nietzsche borrowed immensely and forced this borrowing to a point of distortion. A philosophy of noise? Yet, is it possible to philosophize about noise? Did Nietzsche philosophize about noise?

'On Din and Noise' ${ }^{2}$ by A. Schopenhauer - a rare essay in which a serious philosopher, a philosopher of the will, seriously gets involved in noise and philosophizes about noise. A question of resonance between the cracking of a whip and the will of the philosopher. And also a question of resonance between Schopenhauer and Nietzsche: two types of resonance.

The first type of resonance is about the tension between a philosopher (his resistance) and the interruptive power of the cracking of a whip. Whereas the resonance between Nietzsche and Schopenhauer is a catastrophic event and it gives way to distortion; and, moreover, its giving way to distortion is not something that can be addressed to 'perception' in the Schopenhauerian sense of the word. Already in Nietzsche's first book, The Birth of Tragedy, it is not something which takes place as something visible or audible.This type of resonance between Schopenhauer and Nietzsche is the one with which I would like to put this essay into resonance.

In other words, I would like to remix in this essay what was already remixed by Nietzsche - that is, Nietzsche's remix of the Schopenhauerian tension between will and contemplation into a relationship between the Dionysian and the Apollonian - by way of reintroducing into this remix the question of the hearable. Finally, I will claim that it is one of these two types of getting into resonance which lays bare a certain understanding of noise, and which also forces Schopenhauer to the claim that he heard the noise.

parallax

ISSN 1353-4645 print/ISSN 1460-700X online (C) 2006 Taylor \& Francis

http://www.tandf.co.uk/journals

DOI: $10.1080 / 13534640600956040$ 


\section{The Question of the Immediate}

One possible way of tracing such a moment of distortion between Schopenhauer and Nietzsche passes through a scrutinization of the question of the immediate which can be found located in the way Schopenhauer produces a critique of the symptomatology that is generally presumed to exist between 'the kernel and the shell', ${ }^{3}$ or the inner and the outer nature.

Schopenhauer's critique proceeds by way of pointing to an abyss which is usually forgotten by scientific or conceptual knowledge. What the latter do in face of such an abyss is to bridge it by means of representations. However, since all representations in the end refer to the principle of sufficient reason, they can never give us an adequate knowledge of this kernel, of what lies beyond our representations. Our representations do not belong to the kernel because time, space, and causality are the characteristics of the conceptual knowledge, and, therefore have got nothing to do with this beyond, with this kernel. The essential failure of our representations emanates from the direction they assume when they are producing scientific truth or knowledge. Schopenhauer's critique is not directed towards the impossibility of bridging this abyss between inner nature and outer nature; he claims only that the way we bridge the abyss with conceptual knowledge is wrong. For in the metaphor of shell and kernel the direction is from outside towards inside, that is any act of representation brings its form to what is formless from the outside, and this form does not belong to the kernel. Schopenhauer's aim is therefore to reverse this direction. For him, since the relationship with the kernel cannot be maintained through the mediation of representation, or the concepts, the philosopher must find a way to get rid of mediation by offering a way from inside towards outside.

However, as the two volumes of The World as Will and Representation ${ }^{4}$ bear witness to, how to eliminate the question of mediation proves to be a rather rigorous one, and it is exactly at this point things start becoming more complicated. These moves are most conveniently traceable in the definitions that Schopenhauer produces for terms such as, 'concepts', 'Idea', 'Will', 'Perception', 'the thing-in-itself', 'representation', and also in the way he picks up certain words for certain purposes.

First of all, the move from inside towards outside without mediation is determined by Schopenhauer by an attempt to define the Ideas as in opposition to concepts. Concepts in that respect are characterized by being 'representations of representations'. ${ }^{5}$ This means that their relationship to Will is only secondary whereas that which is in a primary relationship to the Will is the Idea. If the concept's relationship to the Will is determined by the mediation of Ideas of which the concepts are copies; what relates the Idea to Will is Perception (Anschaung). Concepts, the tools of science, cannot function without introducing into their object a temporality and a spatiality: it means that they can produce knowledge about their object only with respect to something else, that is with respect to some other representations. In contrast, Will, or the thingin-itself is that about which only a fixed meaning should be produced. The foremost distinction between Ideas and concepts is maintained by Schopenhauer by referring to Kantian characteristics of the thing-in-itself. Accordingly, Will or the thing-in-itself do not admit any form of causality determined by time and space because 'they are only 
the forms of our knowledge, not qualities of the thing-in-itself. ${ }^{, 6}$ This means that Ideas assume the duty of the "objectification" of the Will, and they are "what Plato called the eternal Ideas or unchangeable forms'. ${ }^{7}$

The term 'objectification' (Objectivation) certainly has a central role in the philosopher's distinctions between concepts and Ideas with respect to representation. For example, whenever it is a matter of a relationship between his favourite concepts, such as between Will and Idea, Body and Will, Will and the thing-in-itself, Schopenhauer pays special care to use 'objectification' instead of representation (Vorstellung). Without doubt, it is because, for Schopenhauer, representation is what concerns the concepts which mediate knowledge only through the shells. In contrast, objectification is the word which is supposed to enable the philosopher to get rid of the question of mediation. ${ }^{8}$ Thus the primary position of an Idea with respect to Will by means of the employment of the word 'objectification' is what saves the Idea from being a representation, a mediation on the way to the Will.

Such a move, or such a privileging of the word 'objectification' over 'representation' thus (only) initially enables Schopenhauer to theorize the immediate by eliminating the question of the mediation, or, to find a place where representation does not apply; and, without doubt, through this move he not only becomes capable of regulating the relationship between his favourite pairs of concepts, but also capable of overcoming the dialectics which govern the conceptual knowledge. This and similar moves take place most spectacularly when Schopenhauer accounts for 1) the relationship between the body and the will; 2) 'On the Possibility of Knowing the Thing-in-Itself' in the second volume of The World as Will and Representation; and, 3) the work of the genius with respect to the call of the sublime.

1) For Schopenhauer, the kernel is the Will and the Will is the thing-in-itself, yet how do we know it? Without doubt, through our body. The body, or, rather the actions of the body, are what make one aware of the immediate relationship between body and the objectification of the will. Objectification is that moment of my being aware of the will through my body's actions without any act of representation (that is, without an image). Schopenhauer thus places the question of the objectification of the will into a framework of a symptomatology where symptoms do not act as representative of anything but as those by means of which the will is objectified in the body. However, in the mean time, he also introduces his favourite term 'Perception' into the discussion. He says: 'The action of the body is nothing but the act of will objectified (objectivierte), i.e., translated into perception (Anschauung). ${ }^{9}$ And what is striking here is that Schopenhauer does not translate into 'Vorstellung' but 'Anschauung'. ${ }^{10}$

For sure, Schopenhauer's intention is to problematize the relationship between the kernel and the shell, and thus to save it from a simple-minded symptomatology. However, does the introduction of the word objectification constitute a different schema, a schema different from representation? Doesn't it mean that that which is problematized is being reappropriated here in a supposedly unproblematical way, as if to call it 'perception' or 'objectification' can save it from a schema of representation? Schopenhauer acts as if there can be a way out of representation, or furthermore, as if one can offer a new model of representation. Everything revolves around this question: 
Is it possible to determine a place where representation does not apply (where the question of mimesis can be forgotten)?

2) That perception (Anschauung) cannot be thought in a schema other than a representational one, haunts the work of the philosopher once again especially in chapter 18 ('On the Possibility of Knowing the Thing-in-Itself') of Volume II.

Here, it is as if Schopenhauer is setting barriers upon barriers against the return of phantoms by reasserting the symptomatology that he already did in the first volume. The immediacy that determines the relationship between will, perception and body this time is taken from a different angle that leads to the upsurging of an immense question: What is the relationship between the Will and the thing-in-itself? Schopenhauer's answer is 'I teach that the inner nature of everything is will and I call the will the thing-in-itself. ${ }^{11}$

In the same chapter, a few paragraphs earlier, Schopenhauer writes about a certain modification that he brings to Kant's theory. He quotes Kant:
All concepts which do not have their basis a perception in space and time (sensuous perception), or in other words, have not been drawn from such a perception, are absolutely empty, that is to say, they give us no knowledge. But as perception can furnish only phenomena, not things-in-themselves, we too have absolutely no knowledge of things-in- themselves. $^{12}$

Schopenhauer admits this but what he is critical of, is that immediacy is what distinguishes Will from all the other objects of knowledge. So as against the nothingness, or the emptiness of the Kantian thing-in-itself, he proposes that the Will which he holds as identical with the thing-in-itself presents us with a 'relative nothing':

If the will were positively and absolutely the thing-in-itself, then this nothing would be absolute, instead of which it expressly appears to us there only as a relative nothing. ${ }^{13}$

Then it means that in contrast to what Schopenhauer defends, the will is not the thingin-itself; it is different from the thing-in-itself for it has some immediate attributes which make themselves felt and known in a representative schema - hence its relative nothingness differentiates it from the absolute nothingness of the thing-in-itself. Then it also means that the Will acts as a representative for the thing-in-itself. The thing-initself reveals itself by using the immediacy of the will.

Strangely enough, without giving us any clues about how this different representative schema differs from the ordinary one, Schopenhauer closes the matter. Apparently, he decides. Yet despite this decision, that is, a decision that decides to theorize the immediate, one realizes - as one reads Schopenhauer - that the immediate cannot be theorized unless within a dialectical schema. What can one do with immediacy? 
Immediacy calls for a theory of the event. Can one theorize the event? Will Schopenhauer accept this call?

3) If all this can be taken as producing a decision upon something which cannot be decided, such a decision requires also an agent who can decide. This agent - a mediator par excellence - is the genius who is mainly characterized by Schopenhauer as an agent with immense powers of contemplation.

If art is characterized with a density for 'pure contemplation' in the name of the apprehension of the Ideas, and their communication to the others, the genius, for Schopenhauer is the agent who is capable of assuming two duties at the same time: 1) apprehension, or perception of the Ideas; and, 2) their communication to the others. ${ }^{14}$

Given these duties, the genius, in other words, is a mediator between the Idea and the artwork. With exceptional powers of contemplation and perception he endeavours to snatch the Ideas from the 'thraldom of the will', ${ }^{15}$ and thus gives them a certain aspect of communicability in works of art. Most important of all, the objects of knowledge of the genius are the Ideas which can be obtained, not via abstractions, that is by referring to other representations, but only through perception. Schopenhauer's stress on the importance of the perception of Ideas is of course related to his interest to preserve the distinction between concepts and Ideas. Therefore, when the genius is related to the contemplation, or the perception of Ideas, in his duty as the mediator between the Idea and the artwork, he should never refer to representation (Vorstellung) which characterizes the concepts. As we have seen before, Schopenhauer introduces different words at different times in order to get away from the determinations of the word, Vorstellung; and this time, with the intention of stressing that the genius's duty has got nothing to do with representation, he employs a different word: repetition (Wiederholung). ${ }^{16}$ Hence, the Ideas apprehended by the genius are not representations of the Will, but their immediate objectifications in his perception, and the artwork which he produces out of them are not the representations of his perceptions but only their 'repetitions'. Thus, the genius's capacity of perceiving the Ideas is determined by the distance he keeps from the call of the Will.

The extreme form of this duty which even threatens the genius's endeavour to be a will-less subject can be found in Schopenhauer's description of the sublime. ${ }^{17}$ Sublime, in Schopenhauer, functions as the genius's resistance to the call of the will - a call which threatens not only the endeavour of genius towards the contemplation of the Idea, but also the theory of the will-less subject of knowledge. Hence, the enumeration of arts in Schopenhauer comes as a response to the danger, a threat which is directed to the subject from the realm of the Will. Arts in that sense constitute a shield against these dangers and protect the subject from such an abolishment. Various arts are thus put into an order according to the degree of protection they present.

Schopenhauer's theory of art is without doubt haunted by the same issues that lead to the question of the untheorizable. However, instead of stressing once again these conflicts that are due to Schopenhauer's application of his theory to arts, ${ }^{18}$ I would like to show next what happens to the question of the untheorizable, the question of the immediate when it comes to theorizing music. Because, one can argue that it is 
especially here Schopenhauer realizes that his theory of the Will suffers greatly from some unresolved conflicts, and he develops some moves which, rather than resolving these conflicts, amplify them to such an extent that music transforms into a 'sublime' object par excellence.

\title{
II. Music
}

\begin{abstract}
After this, we find that there is yet another fine art that remains excluded, and was bound to be excluded, from our considerations, for in the systematic connection of our discussion there was no fitting place for it; this art is music. ${ }^{19}$
\end{abstract}

All the theory of art that Schopenhauer produces until he introduces his theory of music concerns the specular. In other words, under the light of a decision taken to theorize the immediate by means of a different terminology (which nevertheless cannot eliminate the representational character of his theory), all the arts are categorized on the presupposition of a distinction between Anschaunng and Vorstellung, and also the presence of a genius, who will 'perceive' the Ideas and 'repeat' them in his artwork. However, now, Schopenhauer realizes that a theory of music that follows from an unresolved question of the immediate will create problems basically due to following reasons: 1) privileging of Anschauung over Vorstellung does not explain anything anymore when it comes to music because music is aural and escapes the specular; 2) that music is aural means that it is more immediate than other arts, and therefore does not need a mediator as 'objectification in Ideas through Perception'. In face of these difficulties, Schopenhauer miraculates another strategy which even he himself cannot demonstrate or verify. ${ }^{20}$ To paraphrase Schopenhauer, music's relationship to the world is utterly complicated because music, unlike other arts, does not come as a copy of something which precedes it; or, better, that which precedes music cannot be represented. Schopenhauer cannot 'demonstrate ${ }^{21}$ this but it doesn't stop him from another move whereby he takes music one step closer to Will. Hence, he concludes:

Thus music is as immediate an objectification and copy (Abbild) of the whole will as the world itself is, indeed as the Ideas are, the multiplied phenomenon of which constitutes the world of individual things. Therefore music is by no means like the other arts, namely a copy (Abbild) of the Ideas, but a copy of the will itself, the objectivity of which are the Ideas. $^{22}$

When Schopenhauer moves music one step closer to the Will, his intention is obviously to tame what does not fit into specular schema - for, he has realized now, that which does not fit into specular schema is bound to function as a threat to his theory of the sublime, because it is formless (as Will), and given its immediacy, it casts a threat to the genius: it can absorb the genius into itself. ${ }^{23}$

However, there are also other things, dangerous things that this move leads the Schopenhauerian theory unto. First of all, when music is thus pushed closer to the Will, a certain characteristic of arts for Schopenhauer, that is their power of copying (Abbild), 
which is supposed to disappear does not disappear. Hence, he has to preserve 'copying' together with 'objectification'. On the other hand, a relationship of copying can be established only with respect to a model. Yet here, what takes the place of a model is the Will, which by, definition, is formless. If this were a relationship of Vorstellung, yes, then music in this new place could be understood as that which gives form to what is formless. But Schopenhauer says 'objectification' and 'copying'. At that point, we should be reminded of the last resort that Schopenhauer used between the Will and the thing-in-itself in order to explain the immediacy between the two, and the question of the 'relative nothing'. If music does not require the priority of Ideas in order to be music, then it means it has its own power of giving form not via Vorstellung, that is, via representing the Will, but by 'copying' what cannot be represented, which is, according to Schopenhauer, not nothing but a 'relative nothing'. Yet, even so, the relative nothing is that which requires a form in order to be understood as such, and hence, it cannot exist outside a representational schema.

But how is it possible that music can give form to what is formless as long as Schopenhauer doesn't accept that it is a matter of Vorstellung?

Is it music that Schopenhauer is theorizing or something else? ${ }^{24}$

Here is something which does not come after the event. Schopenhauer is treating that which does not come after the event in a dialectical schema. This something is 'music', according to him.

\section{Nietzsche}

In The Birth of Tragedy, there are numerous references to Schopenhauer:

1) In section 5, Nietzsche disagrees with Schopenhauer on the question of the lyric poet because Schopenhauer follows traditional ways in approaching the lyric poetry. ${ }^{25}$ The lyric poetry for both modern aesthetics and Schopenhauer is 'an incompletely attained art that arrives at its goal infrequently and only, as it were, by leaps' ${ }^{26}$ For Nietzsche, on the other hand, the 'I' of the lyric poet, Archilochus, can never be taken as an alibi for a subjectivity because "its "subjectivity", in the sense of modern aestheticians is a fiction'. ${ }^{27}$

2) In section 16, Nietzsche quotes large paragraphs from Schopenhauer on the question of the copy - that 'music is the immediate copy of the will itself'. Does Nietzsche follow here Schopenhauer's will to offer a new mimetic model which was supposed to distinguish music from all the other arts? Or, does he acknowledge Schopenhauer's failure by offering a strange relationship between the kernel and the shell, Dionysos and Apollo, the-thing-in-itself and appearances?

I offer these cases with the intention of pointing out a central issue which, remaining concealed in the discussion, gives way to a notion that all is a matter of what Nietzsche decided to "borrow" from Schopenhauer. This point is where Nietzsche quotes Schiller in order to support his thought on the subject and the lyric poet: 
Schiller has thrown some light on the poetic process by a psychological observation, inexplicable but unproblematic to his own mind. He confessed that before the act of creation he did not have before him or within him any series of images (Bildern) in a causal arrangement, but rather a musical mood (musicalische Stimmung). ('Within me the perception (Empfindung) has at first no clear and definite object; this is formed later. A certain musical mood comes first, and the poetical idea only follows later'). ${ }^{28}$

First of all, what kind of a mood is that? Why is it musical, that is something aural, instead of being something specular? Whether it be aural or specular, perception (Empfindung: 'percept: an impression of an object obtained by use of the senses ${ }^{29}$ ) is what follows a 'musical mood' which ties the act of creation to an experience of the aural. $^{30}$

What I would like to question here is whether in this very quotation Nietzsche sees a passage from chaos to figure, from inner to outer nature, as for example, Schopenhauer would put it, or a certain relationship between two realms which can best be described as 'resonance'? ${ }^{31}$

So now if we return to the question of the lyric poet, Archilochus, in both Nietzsche and Schopenhauer, one essential difference between two philosophers can be found in the differences each assigned to the relationship between the formless and the formed. For Schopenhauer, such a passage requires a fully-formed subject, who is a subject only insofar as its integrity is preserved as against the call of the Will, the formless matter: this step should be taken once and for all, without leaving behind any possibility of a return to the formless (though, as we have seen, in Schopenhauer the experience of the sublime always carries this risk of falling back). Yet for Nietzsche things are obviously different:

Hence our aesthetics must first solve the problem of how the 'lyrist' is possible as an artist - he who, according to the experience of all ages, is continually saying 'I' and running through the entire chromatic scale of his passions and desires. Compared with Homer, Archilochus appals us by his cries of hatred and scorn, by his drunken outbursts of desire. Therefore is not he, who has been called the first subjective artist, essentially the non-artist? ${ }^{32}$

So, for Nietzsche, if there is a border between the formless and the formed, it is there not as a rigid line of separation between two realms but as a border, constituted anew at each attempt of constructing oneself as a subject. In other words, for him, it is a matter of resonance on both sides of a border which constructs and destroys the very border in question, and hence the passage remains always as a problem. Yet, if Nietzsche problematizes this crossing, the passage from chaos to the phenomenal, what should we think about the music that Schiller is talking about?

In order to trace some possible answers for this question, let us concentrate on Nietzsche's way of putting into 'resonance' also the relationship between Dionysos and 
Apollo. For Nietzsche, dreams are where images, figures or appearances (Apollonian forms) are constituted as symptoms of an underlying substratum (Dionysian chaos) - as in a relationship between a kernel and a shell. With respect to its form-giving power, Apollo is therefore the god of the principium individuationis. However, in opposition to that, Dionysos operates as the god of intoxication towards the destruction of what has assumed form. This way of describing the relationship between Dionysos and Apollo is rather well known, however things change dramatically when one adds to this description the following passage in Section 2:

Thus far we have considered the Apollonian and its opposite, the Dionysian, as artistic energies which burst forth from nature herself, without the mediation of the human artist (ohne Vermittelung des menschichen Künstlers) - energies in which nature's art impulses are satisfied in the most immediate and direct way - first in the image world of dreams, whose completeness is not dependent upon the intellectual attitude or the artistic culture of any single being; and then as intoxicated reality, which likewise does not heed the single unit, but even seeks to destroy the individual and redeem him by a mystic feeling of oneness. With reference to these immediate art-states of nature, every artist is an 'imitator' (Nachahmer). ${ }^{33}$

Here, Nietzsche seems to be suggesting that 'artistic' creation happens in a two-fold process where the folds cannot be separated from each other. If the bursting forth of artistic energies (Dionysian and Apollonian) finds an image in one fold in 'the image world of dreams', the other fold, developing in a parallel fashion, is determined by a destruction of these images. Therefore, the artist, within the 'immediate art-states of nature' is the one who never comes into being as such, or as a fully formed subject, because his/her coming into being is always interrupted by a battle between Apollonian and Dionysian forces. Such a relationship between the folds also eliminates the question of the first because, even if the Dionysian forces seem to be secondary in this process, they already contain, and are contained within, Apollonian forces, and the same holds true for the Apollonian forces. In other words, the two opposite forces are put into resonance by Nietzsche just to bar the "subject" from coming into being. And this is why here, Nietzsche does not talk about an artist: the artist only comes too late, after the event, as an imitator of this process with an end product, the work of art. However, as we know it from Nietzsche's formulation of the tragic, the lyrist, ('the nonartist') is the one who can imitate this process in art works so that the Socratic truth never appears as such in a dialectical fashion. In other words, although the relationship between two folds seems to be determined by a model/copy relationship, this relationship is simulacral rather than mimetic because the passage between the formed and the formless is a simultaneous, continuous and a reversible process. Therefore, the essential question for Nietzsche, unlike Schopenhauer, is not 'Can there be an art which actualizes the immediate?' but 'Can art point to the immediate?' For Schopenhauer, as we have seen, this art is music. However, in Nietzsche, this turns into a question that cannot be directly answered. He writes:

In the first place, as a Dionysian artist [the lyrist] he has identified himself with the primal unity, its pain and contradiction. Assuming that music has been correctly termed a repetition (Wiederholung) and a 
recast (zweiter Abguss) of the world, we may say that he produces the copy (Abbild) of this primal unity as music. Now, however, under the Apollonian dream inspiration, this music reveals itself to him again as a symbolic dream image. The inchoate, intangible reflection of the primordial pain in music, with its redemption in mere appearance, now produces a second mirroring as a specific symbol or example. The artist has already surrendered his subjectivity in the Dionysian process. The image that now shows him his identity with the heart of the world is a dream scene that embodies the primordial contradiction and primordial pain, together with the primordial pleasure, of mere appearance. The 'I' of the lyrist therefore sounds from the depth of his being: its 'subjectivity', in the sense of modern aestheticians is a fiction. ${ }^{34}$

I propose that at this juncture we should try to discuss that in the quotation above there are two types of music for Nietzsche. The first is the Dionysian type of music (here the lyrist is one with the primal unity and 'he produces the copy of this primal unity as music'), and it is right there, in face of an impossibility of thinking about music without mimesis, Nietzsche's theory falls out of resonance with Schopenhauer's and thus forces the relationship between the philosophers to resonance, distortion and noise.

The second type of music, the Apollonian one, comes on top of this as in a relationship of a model and a copy ('The inchoate, intangible reflection of the primordial pain in music, with its redemption in mere appearance, now produces a second mirroring as a specific symbol or example'). However, as we have seen above, the strange mimetic relationship between these two types of 'mirroring' is opened up to the simulacral yet with one critical question to be answered now: Is it music that Nietzsche is talking about as far as the first type of music is concerned? Or better, can this 'music' be heard?

For Schopenhauer, as we have seen before, music - theorized within a proximity to the immediate - knows no such Nietzschean distinctions; it supposedly does not, or should not obey to the rule of a model/copy relationship; it can be heard under every circumstances; and it can exist even when there is no one to hear it.

Yet, to obtain such a clarity of thought from Nietzsche is rather difficult because his relationship to the mimetic is determined neither by a rejection nor a pure acceptance. For Nietzsche, in other words, music, in contrast to all the theorization with respect to the question of the immediate, still remains one step away from the 'primal unity' just as all the other arts. Music therefore can only be heard if it is music, that is, if it is formed within a model and copy relationship. However, if in the Nietzschean theory there is still no clear answer as to whether the first type of music can be heard, it is because of the way in which Nietzsche puts two types of music in a simulacral relationship where they are put into resonance, eliminating the question of the first. If one cannot theorize the first type of music, if it is that which escapes the theory, it is not because it cannot be heard but because it remains as the unheard within what is heard. Music and all the other arts are thus given a new position where they all point to the the question of the immediate without claiming to actualize it. The question of the immediate in Nietzsche is no more related to music, but to something unthinkable, or 
untheorizable, or, undecidable, or to something which is there as a different type of relationship between two realms, say, between, the real and the apparent, the will and the idea, the original and the copy, etc. - a matter of resonance and noise. But can one hear the noise?

\section{Noise}

At this juncture, though in an abrupt way, as if to amplify the noise, I would like to be interrupted by a concern for what Schopenhauer thought about noise:

In the same way a great mind is no more capable than an ordinary one, the moment it is interrupted, disturbed, distracted, and diverted. For its superiority is conditioned by its concentrating all its powers, as does a concave mirror all its rays, on to one point and object; and it is precisely here that it is prevented by a noisy interruption. This is why eminent minds have always thoroughly disliked every kind of disturbance, interruption, and diversion, but above all, the violent disturbance caused by din and noise. The most sensible and intelligent of all European nations has even laid down an eleventh commandment, the rule, Never Interrupt! Din is the most impertinent of all forms of interruption, for it interrupts, in fact disrupts, even our own thoughts.[...] Passing now from the genus to the species, I have to denounce as the most inexcusable and scandalous noise the truly infernal cracking of whips in the narrow resounding streets of towns; for it robs life of all peace and pensiveness. ${ }^{35}$

I would like to draw attention to the following possible remarks:

1) In Schopenhauer, the flow of thought is interrupted by the cracking of a whip. That which pertains to a flow is a flow for it pertains to a consideration of thought within time and space. Thought, then, is that which takes place within time and space. The genius is there to think, in time, in a flow, to stop the wheel of Ixion ${ }^{36}$ by perceiving the Ideas. So, what happens to Schopenhauer's flow of thought at the moment of its interruption by a whip is that the latter destroys this schema of time and space in which thought takes place. Where he is drawn to after the experience of this crack is an atemporal and aspatial realm that does not allow him to continue his flow of thought. This atemporal and aspatial realm, as we know, is the realm of the Will according to the philosopher (just as in Homer's description of what happens to those who listen to the Sirens' song: they forget all past and future). It is a dangerous realm for it is where one cannot follow, or constitute a flow of thought - a realm of desires, bodily needs, a realm that is governed by madness. This realm cannot be represented except for this cracking of a whip. Hence, the realm of noise is also the realm of the Will because this is where the chaos is. Is noise that which comes from a realm that Schopenhauer failed to theorize?

2) The problem with this line of thought is that it hears what it describes as the unhearable. When it is heard, it comes as noise, and when it cannot be heard it 
presents itself as Will. And the cracking of a whip constitutes a threshold, an explosive line of demarcation between two realms. On the one side there is the realm of the Will, noise, the thing-in-itself, on the other, there is the realm of flow, harmony, music, thought. And the cracking of a whip is that which disturbs this line of demarcation with a blow and bars the messenger from making its message received.

As if one could conclude: we have music because we cannot hear the 'music'.

\section{The Event}

Let's try to 'visualize', get the 'perception' (Anschaunng) of what happened to Nietzsche at a similar moment of hearing the cracking of a whip. The scene takes place in Turin and it is a moment of collapse. It is usually referred to as follows:

On January the 3rd 1888, Nietzsche was in the piazza Carlo Alberto, in Turin, Italy. Seeing a coachman brutally flog a horse, he intervened, and collapsed, shielding the horse from the whip. Carried back to his lodgings, he comes around, but he is no longer sane. ${ }^{37}$

Can one really perceive, represent, put into images, what happened to Nietzsche when he heard the cracking of the whip? What did Nietzsche hear? The noise that immensely disturbed Schopenhauer? We should doubt it. If it were noise, then it should have disturbed him. Did it disturb him? What is the limit of disturbance? Is 'noise' there for us to hear? Is it possible to be disturbed by noise? An invitation.

Notes

1 Arthur Schopenhauer, 'On Din and Noise', Parerga and Paralipomena [1851], 2 vols, trans. E.F.J. Payne (Oxford: Clarendon Press, 1974; reprint 2000), II, p.645.

2 Arthur Schopenhauer, 'On Din and Noise', pp.642-45.

${ }^{3}$ When I write 'the kernel and the shell,' I have in mind N. Abraham and M. Torok's work on the same subject (The Shell and the Kernel: Renewals of Psychoanalysis, Volume 1, ed. and trans. Nicholas Rand (Chicago: The University of Chicago Press, 1994) and their critique of Freudian symptomatology which led to another work, The Wolfman's Magic Word: A Cryptonomy, trans. Nicholas Rand (Minneapolis: University of Minnesota Press, 1986). Confronted with the impossibility of reaching the truth of the wolfman's crypt, their theory turns into a deconstruction of psychoanalysis, where a clear-cut determination of any possible relationship between the kernel and the shell disappears.

${ }^{4}$ Arthur Schopenhauer, The World as Will and Representation [1819], 2 vols, trans. E.F.J. Payne (New York: Dover Publications Inc, 1969).

${ }^{5}$ Arthur Schopenhauer, The World as Will and Representation, I, p.40.

${ }^{6}$ Arthur Schopenhauer, The World as Will and Representation, I, p.134.

7 Arthur Schopenhauer, The World as Will and Representation, I, p.170.

8 '...for us the Idea is only the immediate, and therefore adequate, objectivity of the thing-in-itself,' Arthur Schopenhauer, The World as Will and Representation, I, p.74.

9 Arthur Schopenhauer, The World as Will and Representation, I, p.100.

${ }^{10}$ See especially Arthur Schopenhauer, The World as Will and Representation, I, pp.103-4 for how such a privileging leads to contradictory conclusions where the body is taken both as a representation and not a representation.

11 Arthur Schopenhauer, The World as Will and Representation, II, p.197.

${ }^{12}$ Arthur Schopenhauer, The World as Will and Representation, II, p.196.

13 Arthur Schopenhauer, The World as Will and Representation, II, p.198.

Aracagök 
14 Arthur Schopenhauer, The World as Will and Representation, I, p.185.

15 Arthur Schopenhauer, The World as Will and Representation, I, p.196.

${ }^{16}$ See Arthur Schopenhauer, The World as Will and

Representation, I, pp.194-5. In other words, the genius - instead of representing - repeats in the artwork what he has perceived in the Idea.

17 See Arthur Schopenhauer, The World as Will and Representation, I, pp.201-2.

${ }^{18}$ For a detailed discussion on Schopenhauer's examination of the conditions for art's foundation see, Cheryl Foster. 'Ideas and Imagination' in The Cambridge Companion to Schopenhauer, ed. C. Janaway (Cambridge: Cambridge University Press, 1995), pp.213-251.

19 Arthur Schopenhauer, The World as Will and Representation, I, pp.255-6.

20 'I recognize, however, that it is essentially impossible to demonstrate this explanation, for it assumes and establishes a relation of music as a representation (Vorstellung) to that which of its essence can never be representation, and claims to regard music as the copy (Nachbild) of an original (Vorbildes) that can itself never be directly represented.' Arthur Schopenhauer, The World as Will and Representation, I, p.257.

21 That Schopenhauer cannot verify this point is worked by Lawrence Ferrara in 'Schopenhauer on Music as the Embodiment of Will' in Schopenhauer, Philosophy and the Arts, ed. D. Jacquette (Cambridge: Cambridge University Press, 1996), pp.183-199. With respect to a thorough analysis of the work of Jean-Philippe Rameau, who appears as the prime example of Schopenhauer's understanding of music. The main point of the article is to foreground a certain sense of merging of referentialism and formalism in Schopenhauer's theory of music.

22 Arthur Schopenhauer, The World as Will and Representation, I, p.257.

23 Let's stop for a moment, and accept Schopenhauer's theory without questioning his main presumption: if one cannot show, or demonstrate the represented, then it is a matter of immediacy that concerns and differentiates music from the other arts. Yet, wouldn't then all the universe be transformed into a giant music machine without a composer, or a performer? What kind of a music is that? What happened to the genius? Why has he disappeared from the theory? Has the moment of sublime swallowed the genius? Certainly, Schopenhauer has an answer for that: music can exist even when there is no one to perceive it (see especially, Arthur Schopenhauer, The World as Will and Representation, I, p.257).

24 Approaching this issue from a different angle, Lydia Goehr's article takes the contradictions of
Schopenhauer's theory of music as bearing witness to the limits of theory which ends up in silence. She writes: 'Schopenhauer revealed more about music through silence than speech, through what he showed indirectly by analogy than through what he was able to say literally. In this view, speech and silence, like saying and showing, are mutually dependent or correlative concepts. Accordingly what cannot be said or what belongs to silent discourse is revealed only by contrast to what can be said. The limits of what can be said determine the limits of what can be shown; or the world of speech delimits the boundaries which the world of silence must transgress'. Lydia Goehr, 'Schopenhauer and the musicians: an inquiry into the sounds of silence and the limits of philosophizing about music' in Schopenhauer, Philosophy and the Arts, ed. D. Jacquette (Cambridge: Cambridge University Press, 1996), pp.200-28 (p.215).

25 'Schopenhauer, who did not conceal from himself the difficulty the lyrist presents in the philosophical contemplation of art, thought he had found a way out on which, however, I cannot follow him.' Friedrich Nietzsche, The Birth of Tragedy, trans. Walter Kaufmann (New York: Vintage Books, 1967) p. 51

${ }^{26}$ Friedrich Nietzsche, The Birth of Tragedy, p.51.

27 Friedrich Nietzsche, The Birth of Tragedy, p.49.

${ }^{28}$ Friedrich Nietzsche, The Birth of Tragedy, p.49.

${ }^{29}$ http://www.m-w.com/cgi-bin/dictionary

${ }^{30}$ Quoting the same passage in his work, Phillipe Lacoue-Labarthe offers the following remarks: 'Nietzsche refers to this statement not only to prove the anteriority of the Dionysian (let us say, for the sake of simplicity, the musical) in relation to the Apollonian - concept, image, figure, etc. He cites it also, as demonstrated on the subsequent page, in order to attempt to think the unthinkable passage from chaos to figure, from the originary One ('which is pain and contradiction') to phenomenality in general. [...] At the same time, and on the other hand, it is to show out of what abyss of the subject, out of what impossible originary identification with originary suffering is formed (sich bildet), through the mediation of the example (which is to say, for Nietzsche, the myth, or, if you will, identification in the common sense of the term), the 'subject' in its modern definition - that 'illusion'. Philippe Lacoue-Labarthe, Typography, trans. Christopher Fynsk (California: Stanford University Press, 1989), p.186.

${ }^{31}$ A concept which I elaborated in an earlier essay, 'On Rhythm, Resonance and Distortion', Pli - The Warwick Fournal of Philosophy, 14, (2003), pp.129-156.

${ }^{32}$ Friedrich Nietzsche, The Birth of Tragedy, p.48.

${ }^{33}$ Friedrich Nietzsche, The Birth of Tragedy, p.38. 
${ }^{34}$ Friedrich Nietzsche, The Birth of Tragedy, p.49.

35 Arthur Schopenhauer, 'On Din and Noise', pp.642-43.
${ }^{36}$ Arthur Schopenhauer, The World as Will and Representation, I, p.196.

${ }^{37}$ http://www.demon.co.uk/natofeur/also.html

Zafer Aracagök teaches continental philosophy at Bilkent University, (TR). He is the author of three books (in Turkish) and various journal articles addressing the issues of image, resonance and noise in continental philosophy and in the philosophy of Deleuze and Guattari. Aracagök is also an electronic music artist (SFR-Zero) with recent works such as, 'I'm Stupid because I'm Dead I'm Dead because I'm Stupid' (which is about Nietzsche's collapse in Turin), released by Ada Records in Istanbul 2005, and 'Divide by Zero' (in collaboration with Yolande Harris) to be released soon by Persistencebit Records in Italy. Forthcoming articles include 'Retenir La Ritournelle', in Deleuze, Guattari et le politique, ed. M. Antonioli (L'Harmattan, Paris). 